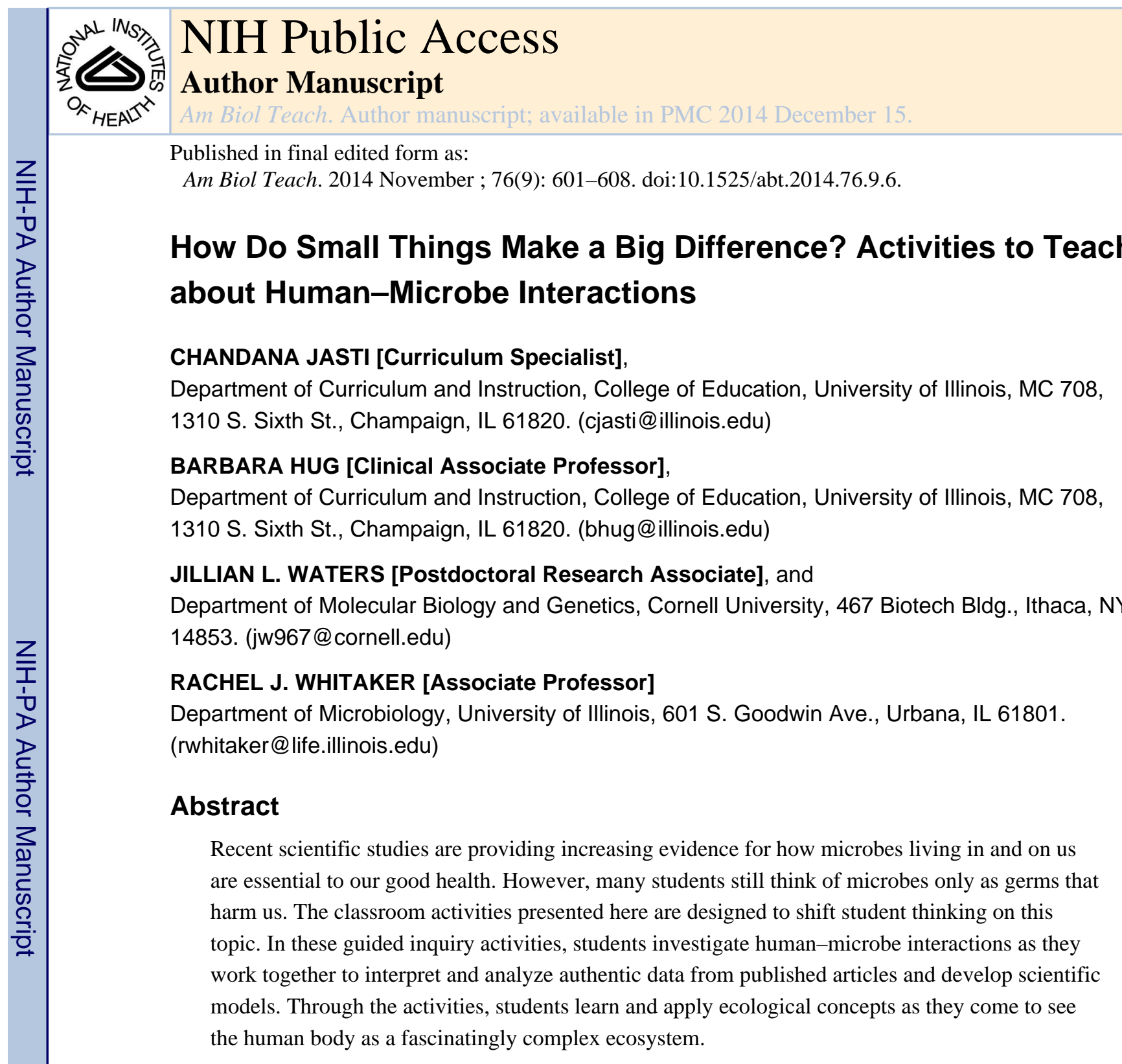

\title{
Keywords
}

Inquiry instruction; curriculum development; NGSS; models; data analysis; high school biology; microbiology; human health

\begin{abstract}
A recent issue of The New York Times Magazine ran a cover story on "The secret lives of germs: What we can learn from our microbiome." The issue featured an article titled "Some of my best friends are germs" (Pollan, 2013). In the same year, National Public Radio ran a special series in health news called The Human Microbiome: Guts and Glory, airing stories such as "Microbe transplants treat some diseases that drugs can't fix" and "From birth, our microbes become as personal as a fingerprint" (Stein, 2013c). News articles, reports, and blog posts such as these continue to highlight how microbes play a more significant role in our world than we had ever imagined. Microbes populate nearly every nook and cranny of the human body. They make up our microbiome, educate our immune system, protect us from infections, are critical to digestion, and much more. These media stories, grounded in
\end{abstract}


the current scientific research, push us to think of ourselves not simply as individuals, but rather as complex ecosystems of microbes.

Despite the findings of microbiology research, many students continue to think of microbes primarily as disease-causing germs and have very little idea of the beneficial aspects of microbes (Driver et al., 1994; Byrne, 2011). These misconceptions highlight the need to not only expose students to recent scientific developments in micro biology, but also to develop their skills for scientific literacy so that they are able to decipher new scientific information they encounter. To this end, Project NEURON and Project MICROBE worked in collaboration to develop two lessons designed to shift student thinking about humanmicrobe interactions through activities that provide scaffolded opportunities for students to engage with primary scientific literature and popular science articles. The lessons - titled "How do microbes interact with humans?" and "What can happen when my microbiome is disturbed?" - introduce students to the populations of microbes that live in and on us, the roles they play, and what can happen to our microbial ecosystem when a disturbance occurs. Students investigate these driving questions by reading scientific text and analyzing, interpreting, and discussing authentic, published data presented in an accessible manner.

\section{Unit Overview}

The two lessons are part of a high school curriculum unit titled "How Do Small Things Make a Big Difference? Microbes, Ecology, and the Tree of Life." The unit highlights the important roles and diversity of microbes and encourages students to think about the complex and dynamic ecosystems in which they exist. Table 1 provides an overview of the unit with each lesson's title (also the driving question) and description. Here, we describe in depth the last two lessons: "How do microbes interact with humans?" and "What can happen when my microbiome is disturbed?" All lesson materials are freely available online from the Project NEURON website (http://neuron.illinois.edu).

\section{Connections to the Literature}

Design of the curriculum materials was informed by the educational literature on contextualized instruction and modeling in science learning (National Research Council [NRC], 2000; NRC, 2005). The activities in the two lessons contextualize learning by focusing on issues that are relevant to the lives of the learners (i.e., the human microbiome and antibiotic use; Rivet \& Krajcik, 2008). Students also make real-world connections to current research by examining authentic published data and using it as evidence to construct their own understanding of the scientific phenomenon. These aspects of contextualized instruction allow students to connect personally with the content, which can increase their interest and motivation to learn and their ability to make meaningful connections between the scientific principles and their own understanding of how things work (Rivet \& Krajcik, 2008).

Additionally, the activities use a model-based inquiry approach to engage students meaningfully with the content (NRC, 2005; Windschitl et al., 2008). Students develop a model based on their initial understandings, test their ideas against new information (i.e., science readings and published data), and then revise their initial model to account for this 
new information. By using models in this manner, students organize and explain scientific ideas, communicate information, and engage in the metacognitive practice of revising models on the basis of new understandings. Through this process, students develop a deeper and more connected understanding of the science (Windschitl et al., 2008; Schwarz et al., 2009).

\section{Connections to the Framework \& NGSS}

These ideas of contextualizing learning and using models in science are present in the Next Generation Science Standards (NGSS; NGSS Lead States, 2013), which are grounded in A Framework for K-12 Science Education (Framework; NRC, 2012) and the larger scienceeducation literature. The NGSS and the Framework are driving forces in current reform efforts in K-12 science education. Using the Framework as a foundation, the NGSS provide new standards, or "performance expectations," which integrate the three dimensions of science outlined in the Framework. When integrated to frame science instruction, these three dimensions - disciplinary core ideas (DCIs), scientific practices, and crosscutting concepts encourage more comprehensive and meaningful learning of science and the scientific process. As states adopt the NGSS, incorporating these new standards into classroom instruction will become increasingly important. Table 2 lists the DCIs, scientific practices, and crosscutting concepts that connect with the two lessons discussed in this paper. It is important to note that the NGSS performance expectations are not the curriculum, but rather identify what students should know and be able to do as a result of classroom instruction. In keeping with this philosophy, the curriculum materials discussed here prepare students to meet the relevant performance expectations listed in Table 3.

\section{Lesson Description: How Do Microbes Interact with Humans?}

This lesson introduces students to some of the many roles that microbes play in and on our bodies. Students investigate the driving question through an ecology lens by studying adapted scientific literature and interpreting graphical data. The lesson has a modular design so that new readings that incorporate recent discoveries can be added to keep the main activity current with advances in scientific understanding. The "How do microbes interact with humans?" lesson is expected to take up to three 50-minute class periods, though times will vary by context. The learning goals for the lesson are summarized here:

1. Explain different roles of microbes in and on the human body.

2. Apply ecological concepts to the context of human-microbe interactions.

3. Analyze and interpret scientific data to draw and support conclusions about the roles of microbes in and on the human body.

4. Develop and use models to explain and communicate information about humanmicrobe interactions.

The learning goals are achieved through a guided jigsaw activity (Figure 1). Students begin with their home groups, where they together draw an initial model to answer the lesson's driving question: How do microbes interact with humans? Students draw on their own prior knowledge to develop an initial explanatory model. At this point in the lesson, there is no 
right or wrong answer - students are simply developing a model to communicate their current understanding of the science. This is a good opportunity for teachers to take note of the students' preconceptions (and perhaps misconceptions), which can then help guide lesson instruction.

After completing their initial models of human-microbe interactions, students split into "expert" groups, each of which is responsible for one or a subset of readings. Lesson plan materials include six student readings, each covering a different example of human-microbe interactions (Table 4). The readings are each 1-2 pages and include text, diagrams, and graphs to describe and illustrate the phenomenon. Readings and figures are based on current scientific and popular science papers (cited in Table 4) that provide insight into humanmicrobe interactions and expose students to current research. For example, Figure 2 (a diagram in the "Our Skin Microbiome" reading) is a graphical representation of data illustrating the diversity and ubiquity of skin microbes.

Accompanying each of the readings are questions that guide students in making sense of the information presented, analyzing the data, and forming connections to ecological concepts. Students work together to answer these questions and become "experts" on their topic. When teaching this lesson, teachers continuously move around the classroom and ask students questions to help them understand and extend concepts and ideas. The provided readings vary in com plexity and difficulty, allowing teachers to differentiate instruction as appropriate for their students.

In the third phase of the activity, students return to the home groups with whom they created their initial model of the human microbiome. This group should now have an expert on each of the different topics included in the lesson. Their first task as a group is to communicate to each other the information they obtained and evaluated in their expert groups. Students are guided in their home-group discussion through a range of questions and prompts, such as

- Why is microbial diversity important to human health?

- Provide examples of ecological niches that microbes fill in or on the human body.

- Explain how microbes protect us.

- Give examples of commensal and mutualistic relationships between microbes and the human body.

- Describe how native and non-native microbes can become invasive species in the human body.

- You recently told your friend in another biology class that the human body is an ecosystem. He doesn't believe you; he tells you that ecosystems are places like the forest, ocean, desert, etc. What do you explain to your friend to convince him that the human body is, in fact, an ecosystem?

Complete answers for many of the questions and prompts require students to draw on multiple readings, encouraging rich discussions and synthesizing of ideas to develop a larger conceptual understanding. 
As students collaborate to combine their expertise on different microbial communities and roles, they also revise the initial model they developed to begin the lesson. This process engages students in the scientific practice of using and revising models as new information is learned (Table 2; NRC, 2012; NGSS Lead States, 2013). In addition to revising the models, students are encouraged to think about this process in a metacognitive fashion, explicitly stating how they are revising the model and why. In some cases, students may simply add to their initial model to give it more explanatory power based on the new information they gathered from the readings, or they may jettison parts of their initial model that are no longer consistent with the new information.

Finally, each group presents their revised model to the class. This can be done either as a whole class or in a conference style, whereby all groups set up their model and take turns visiting other posters. Students should be encouraged to ask each other questions about their model (as a way of testing the explanatory power of the model). For assessment, students' revised models can be evaluated on the basis of criteria such as explanatory power, use of scientific data to support the model, and revision of a model (Table 5; Schwarz et al., 2009). Teachers should adapt this example rubric to address the needs of their classroom.

\section{Lesson Description: What Can Happen When My Microbiome Is Disturbed?}

Building on students' knowledge of the roles, diversity, and ubiquity of microbes in and on the human body, this lesson provides an opportunity to investigate disturbances to that microbiome. The activities described here take approximately two 50-minute class periods (times will vary by context). Summarized below are the learning goals for this lesson:

1. Define and apply ecology concepts of disturbance, resilience, recovery, and diversity in the case of a human gut-microbiome disturbance.

2. Analyze and interpret graphs demonstrating the effects of infection and antibiotics on the human microbiome.

3. Compare and contrast the effectiveness of two different antibiotics in treating a bacterial infection.

4. Practice developing a claim and supporting it with evidence and reasoning.

The lesson is divided into three main parts (Case Study Parts A, B, and C) to help students work through a case study to explore the effects of bacterial infections and antibiotics on the gut microbiome while drawing on and adding to their knowledge of the human microbiome and ecosystem dynamics. The case study's experiment design and data are based on a clinical trial published by Louie et al. (2012) and are presented in a way that is accessible to high school students. The clinical trial tests two different antibiotic treatments for patients infected with Clostridium difficile ( $C$. difficile), a bacterium that can cause severe diarrhea and even death if it grows uncontrollably (Mayo Clinic, 2013).

\section{Case Study Part A: Background \& Hypothesis}

Students are introduced to the case study through the Case Review Part A document that covers background information on $C$. difficile infection (CDI), effects of antibiotics, and the 
clinical trial process. The document explains that numerous patients at Central Midwest Hospital (a fictional hospital with a very real problem) are suffering from CDI. Vancomycin is the antibiotic typically used to treat CDI; however, there is a high rate of recurrence of the infection when this treatment is used. Dr. Rivera (a fictional person) wants to test the effectiveness of a new antibiotic, fidaxomicin. He will conduct a clinical trial in which half the patients are treated with vancomycin and half are treated with fidaxomicin. Dr. Rivera thinks that fidaxomicin will disrupt the populations of commensal microbes less than vancomycin and, therefore, will be more effective in treating CDI.

Students are asked to help Dr. Rivera by developing models that explain the hypothesized effectiveness of each of the two antibiotics in treating and preventing recurrence of CDI. In order to do this, students must consider several concepts: the role of commensal microbes in competing with harmful microbes, conditions that foster an infection, and the effects of the antibiotics on the gut microbial ecosystem.

\section{Case Study Part B: Methods \& Data Analysis}

Case Review Part B explains the methodology for the published study. The study (as part of a larger clinical trial) includes 89 patients with CDI, half of whom are randomly assigned to vancomycin treatment and half to fidaxomicin treatment. A double-blind method is used in which neither the patients nor those who administer the treatment know which antibiotic is given. Antibiotics are administered for 10 days, and the patients are followed for several weeks. Dr. Rivera's research team collects fecal samples from the study participants periodically throughout the approximately 40 -day trial. Fecal samples from 10 vancomycintreated patients, 10 fidaxomicin-treated patients, and 10 healthy controls are analyzed to evaluate the effects of antibiotic treatment on the microbiome. Since each microbial group has a unique DNA sequence, the team quantifies the amounts of different types of microbes through DNA analysis of fecal samples. For each patient, the team measures the amount of C. difficile (Figure 3A) as well as some commensal microbial types: Bacteroides, Prevotella, Clostridium coccoides, and Enterococcaceae group (Figure 3B-E, respectively). Each data point in the graphs represents the average of microbial counts from the 10 patients in each treatment group. Levels of the commensal microbial groups are also measured in a group of 10 healthy people and averaged for a point of comparison (indicated in Figure 3B-E). The graphs are recreated from data published in Louie et al. (2012) in order to be more accessible to high school students. Additionally, the study results show that 23\% (10 of 44) of vancomycin-treated patients and $11 \%$ (5 of 44) of fidaxomicin-treated patients experienced CDI recurrence. (Students are provided this information in the form of a piechart.)

The Student Investigation sheet provided in the lesson materials guides students through meaningful analysis of these graphs. The following are just some of the types of questions and prompts students answer in order to make sense of the data:

- Compare and contrast the $C$. difficile counts found in each of the two treatment groups. 
- How do the counts of microbes found in healthy individuals compare with the counts of these same microbes in each of the treatment groups?

- Would you expect to see differences in the number of recurrences for each treatment group? Based on Figure 3A? Based on Figure 3A-E? Explain your answers.

- Why might there be higher rates of CDI recurrence when treated with vancomycin than when treated with fidaxomicin? Explain your answer.

- What is the suggested link between population and diversity of commensal microbes and the recurrence rate of CDI?

The final question in case study Part B asks students to revisit their initial models (developed in Part A) of the effects of the antibiotics and to revise them based on information they gather from the study results.

As students work in groups to analyze the graphs and answer questions, they apply knowledge gained from earlier lessons about the human microbiome and population dynamics concepts, such as competition, to explain the study's results. Students' conversations can extend beyond the listed questions to discuss the prevalence and potential consequences of antibiotic use and antibiotic resistance.

\section{Case Study Part C: Engaging in Argument from Evidence}

Students conclude the case study by answering the question "Which antibiotic, vancomycin or fidaxomicin, is better suited for treatment of CDI?" They are guided to develop a complete and thoughtful answer using the claim, evidence, and reasoning framework (Berland \& McNeill, 2010; McNeill \& Krajcik, 2012). Students develop a claim that answers the question and provide evidence from the data to support their claim. A key component of their answer is the reasoning: students must explain how the evidence they provide supports the claim. This is where students demonstrate their ability to explain study results through the application of ecological concepts. By answering the question in this structured format, students take part in the scientific practice of engaging in argument from evidence (NGSS Lead States, 2013).

The data presented in this lesson highlight the importance of considering multiple possible effects, direct and indirect, of antibiotics. It is important for teachers and, in turn, students, to recognize that this case study illustrates a small portion of the much larger and highly complex science of the effects and consequences of antibiotic use. Students should be encouraged to continue to consider the potential advantages and disadvantages of antibiotic use and to acknowledge the complexity of the issue.

During classroom enactment of this lesson, students can be assessed on the thoroughness and accuracy of their responses in the student sheets as well as the presentations of their final scientific arguments. Teachers should closely monitor students' conversations as they collaborate and discuss ideas in their groups in order to guide and scaffold student understanding. Students' scientific arguments can be assessed using the base rubric provided in McNeill \& Krajcik (2012, p. 114). Teachers are encouraged to expand on this rubric and 
to make it specific to their instruction of the lesson. In developing their scientific arguments, students will likely require support in providing multiple pieces of evidence (and using data as evidence) to support their claim and clear reasoning to back up the evidence.

\section{From the Classroom}

Several teachers have reported on using these lessons in a range of high school biology courses, including AP Biology, Accelerated Biology, and Freshman Biology. Teachers reported that they chose to use these lessons because the materials provided a more applied, current, relevant, and engaging way for students to learn about micro-biology. The activities helped students develop an in-depth answer to the question "Why should we care about microbes?"

Teachers found that the lessons increased students' motivation to learn about microbes because the content was presented in the context of relevant and current real-life examples that allowed them to form a personal connection to the science content. Through the human microbiome readings, students learned about the microbes essential to their everyday life and health. For example, students in the pilot classrooms were intrigued as they interpreted the pie charts of microbial population distributions (Figure 2) while simultaneously pointing to the corresponding part of themselves and recognizing that they were covered in microbes. Another reading popular with students was the idea of fecal transplants as a treatment for bacterial infection. Though it was initially the "ick" and shock factors that caught students' attention, they moved into engaging and insightful discussions, reasoning through how it could make sense scientifically and whether patients would be receptive to such a treatment. This conversation, which started during the jigsaw activity, continued as they learned about effects of infections and antibiotics in the following lesson. In the case study, students investigated the effects of antibiotics on the microbiome - something they had likely never considered before, but the importance and personal relevance of which they quickly realized. Teachers remarked, and we observed, that as they worked through these lessons, students began to think of themselves as complex ecosystems filled with a diversity of microbes playing different roles.

Exposure to current scientific literature and popular-press articles also appeared to have an impact on students. One teacher reported that students added to the curriculum materials by seeking out and bringing in additional current news articles on microbes. This suggests that, through the instructional approach taken in these lessons, students recognized the connections to current science and the importance of learning more about new scientific developments - a goal highlighted in the new science education standards.

In summary, the two lessons described here broaden students' understanding of the diverse roles of microbes and the vital roles they play in our everyday existence. The materials connect to students' lives and engage students in scientific practices, capturing their interest, and making learning meaningful. 


\section{Acknowledgments}

We are grateful to the participating teachers for welcoming us into their classrooms and providing feedback. We acknowledge Hillary Lauren for creating figures for the manuscript and curriculum materials and Kristen Talbot, Sara Adamek, Sahid Rosado Lausell, and James Henriksen for their work on the lessons highlighted in this paper. We thank General Microbiology MCB300 honors students at the University of Illinois for development of additional readings. Project NEURON (http://neuron.illinois.edu) is supported by Office of the Director, National Institutes of Health (NIH), under award no. R25OD011144. Additional support was provided by the Institute for Genomic Biology, University of Illinois, which allowed the development of the "How Do Small Things Make a Big Difference?" unit. Funding to Rachel Whitaker for Project MICROBE was provided by National Science Foundation (NSF) grant DEB:0816885. The content is solely the responsibility of the authors and does not necessarily represent the official views of the NIH, the NSF, or the University of Illinois.

\section{References}

Atarashi K, Tanoue T, Shima T, Imaoka A, Kuwahara T, Momose Y. Induction of colonic regulatory T cells by indigenous Clostridium species. Science. 2011; 331:337-341. others. [PubMed: 21205640]

Berland LK, McNeill KL. A learning progression for scientific argumentation: understanding student work and designing supportive instructional contexts. Science Education. 2010; 94:765-793.

Byrne J. Models of micro-organisms: children's knowledge and understanding of micro-organisms from 7 to 14 years old. International Journal of Science Education. 2011; 33:1927-1961.

Driver, R.; Squires, A.; Rushworth, P.; Wood-Robinson, V. Making Sense of Secondary Science: Research into Children's Ideas. Routledge; London, UK: 1994.

Grice EA, Kong HH, Conlan S, Deming CB, Davis J, Young AC. Topographical and temporal diversity of the human skin microbiome. Science. 2009; 324:1190-1192. others. [PubMed: 19478181]

Grice EA, Segre JA. The skin microbiome. Nature Reviews Microbiology. 2011; 9:244-253.

Kim KS. Mechanisms of microbial traversal of the blood-brain barrier. Nature Reviews Microbiology. 2008; 6:625-634.

Kong HH. Skin microbiome: genomics-based insights into the diversity and role of skin microbes. Trends in Molecular Medicine. 2011; 17:320-328. [PubMed: 21376666]

Louie TJ, Cannon K, Byrne B, Emery J, Ward L, Eyben M, Krulicki W. Fidaxomicin preserves the intestinal microbiome during and after treatment of Clostridium difficile infection (CDI) and reduces both toxin reexpression and recurrence of CDI. Clinical Infectious Diseases. 2012; 55(Supplement 2):S132-S142. [PubMed: 22752862]

Mathur R, Amichai M, Chua KS, Mirocha J, Barlow GM, Pimentel M. Methane and hydrogen positivity on breath test is associated with greater body mass index and body fat. Journal of Clinical Endocrinology and Metabolism. 2013; 98:E698-E702. [PubMed: 23533244]

Mayo Clinic. Diseases and conditions: C. difficile infection. [Online.]. 2013. Available at http:// www.mayoclinic.org/diseases-conditions/c-difficile/basics/causes/con-20029664

McNeill, KL.; Krajcik, J. Supporting Grade 5-8 Students in Constructing Explanations in Science: The Claim, Evidence, and Reasoning Framework for Talk and Writing. Pearson Education; Boston, MA: 2012.

National Research Council. How People Learn: Brain, Mind, Experience, and School. National Academies Press; Washington, DC: 2000.

National Research Council. How Students Learn: History, Mathematics, and Science in the Classroom. National Academies Press; Washington, DC: 2005.

National Research Council. A Framework for K-12 Science Education: Practices, Crosscutting Concepts, and Core Ideas. National Academies Press; Washington, DC: 2012.

NGSS Lead States. Next Generation Science Standards: For States, By States. National Academies Press; Washington, DC: 2013.

Palmer C, Bik EM, DiGiulio DB, Relman DA, Brown PO. Development of the human infant intestinal microbiota. PLoS Biology. 2007; 5:e177. [PubMed: 17594176] 
Pollan, M. Some of my best friends are germs. New York Times Magazine; May 15. 2013 Available online at http://www.nytimes.com/2013/05/19/magazine/say-hello-to-the-100-trillion-bacteriathat-make-up-your-microbiome.html?pagewanted=all\&_r=0

Rivet AE, Krajcik JS. Contextualizing instruction: leveraging students' prior knowledge and experiences to foster understanding of middle school science. Journal of Research in Science Teaching. 2008; 45:79-100.

Rowan, K. "Poop transplants" may combat bacterial infections. Live Science [online]. 2012. Available at http://www.livescience.com/36701-poop-transplants-bacterial-cdiff-infections.html

Samuel BS, Gordon JI. A humanized gnotobiotic mouse model of host-archaeal-bacterial mutualism. Proceedings of the National Academy of Sciences. 2006; 103:10011-10016.

Schwarz CV, Reiser BJ, Davis EA, Kenyon L, Archer A, Fortus D. Developing a learning progression for scientific modeling: making scientific modeling accessible and meaningful for learners. Journal of Research in Science Teaching. 2009; 46:632-654. others.

Stein, R. From birth, our microbes become as personal as a fingerprint [radio series episode]. Morning Edition.. National Public Radio; Washington, DC: 2013a.

Stein, R. All Things Considered. National Public Radio; Washington, DC: 2013b. Microbe transplants treat some diseases that drugs can't fix [radio series episode]..

Stein, R. The Human Microbiome: Guts and Glory [radio series]. National Public Radio; Washington, DC: $2013 \mathrm{c}$.

Vignali DA, Collison LW, Workman CJ. How regulatory T cells work. Nature Reviews Immunology. 2008; 8:523-532.

Windschitl M, Thompson J, Braaten M. Beyond the scientific method: model-based inquiry as a new paradigm of preference for school science investigations. Science Education. 2008; 92:941-967. 
Microbes populate nearly every nook and cranny of the human body. 

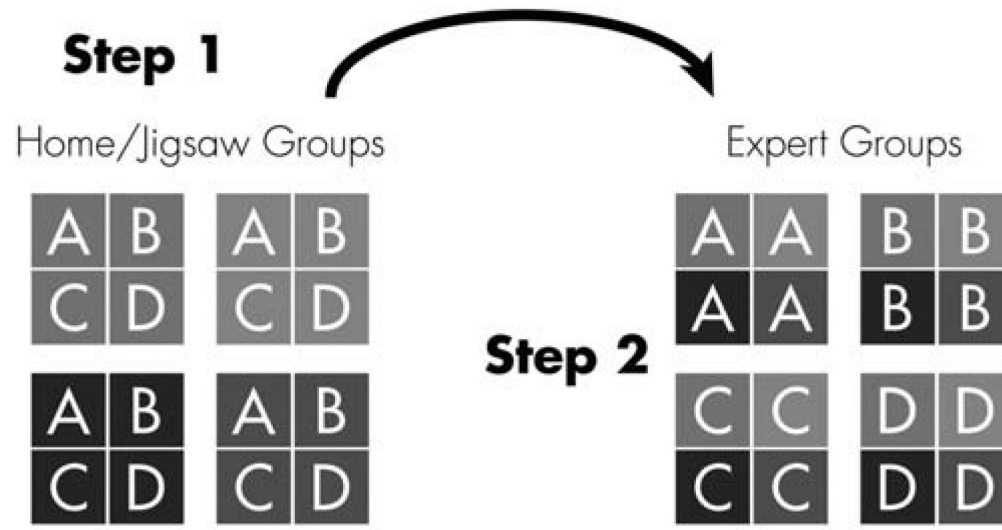

Step 2
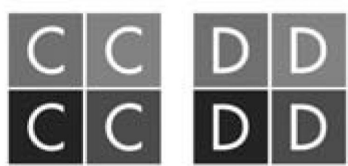

\section{Step 3}

Figure 1.

Diagram of jigsaw activity. First, students meet in their home groups to develop a model based on their existing knowledge (step 1). Then they break out into "expert" groups in which they study and discuss a research article, each expert group analyzing a different article or subset of articles (step 2). Finally, students return to their home groups to revise their initial model after reporting, discussing, and synthesizing their new knowledge (step 3). 


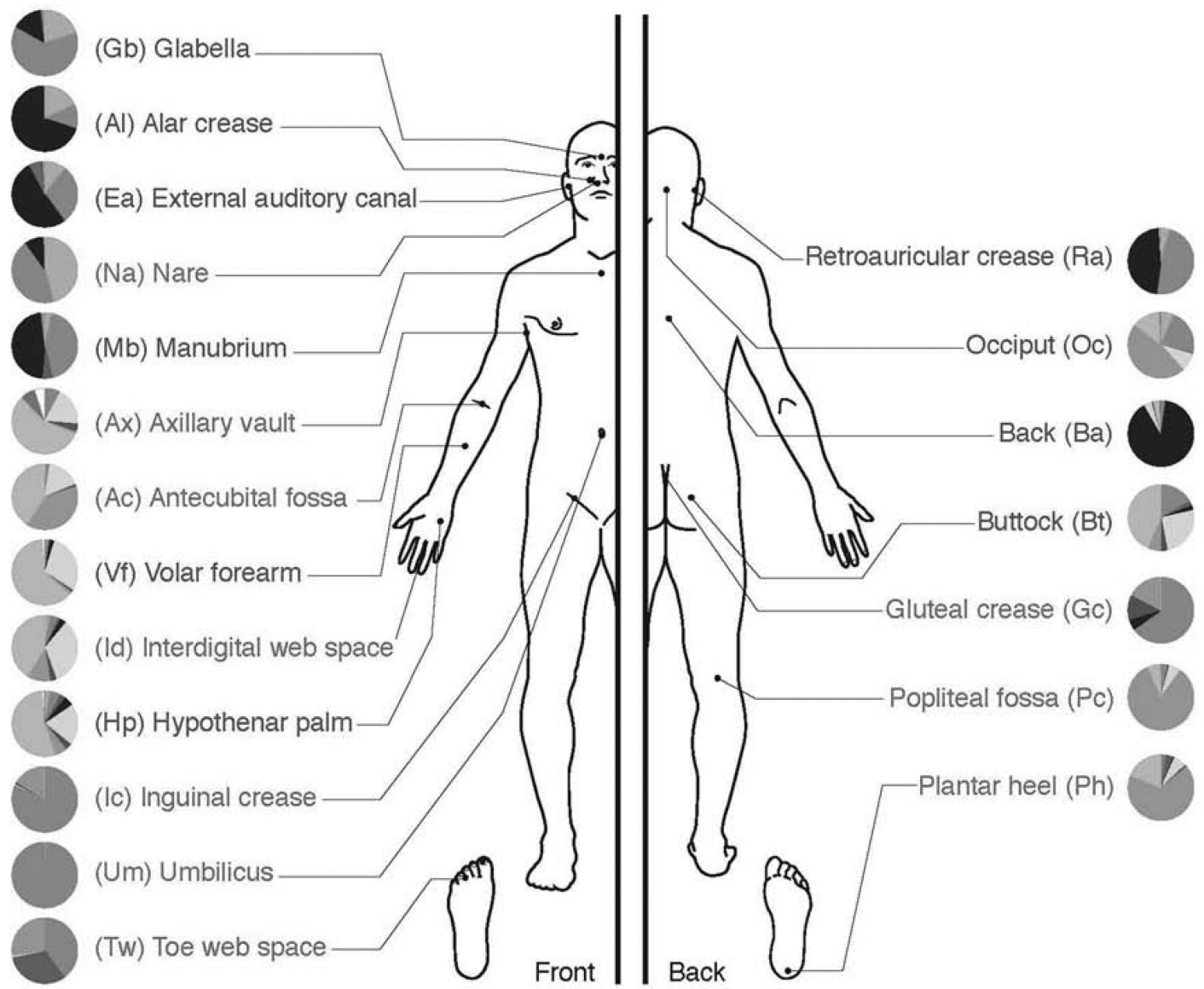

\begin{tabular}{|l} 
Actinobacteria \\
Corynebacterineae \\
Propionibacterineae \\
Micrococcineae \\
Other Actinobacteria \\
Bacteroidetes \\
Cyanobacteria \\
Firmicutes \\
Other Firmicutes \\
Staphylococcaceae \\
Proteobacteria \\
Divisions \\
contributing < 1\% \\
Unclassified
\end{tabular}

Figure 2.

A graphical representation of the distribution of microbes on various skin sites (based on data from National Institutes of Health; graphic credit: Darryl Leja, National Human Genome Research Institute, http://www.genome.gov/dmd/img.cfm?node=Photos/ Graphics\&id=85320). 

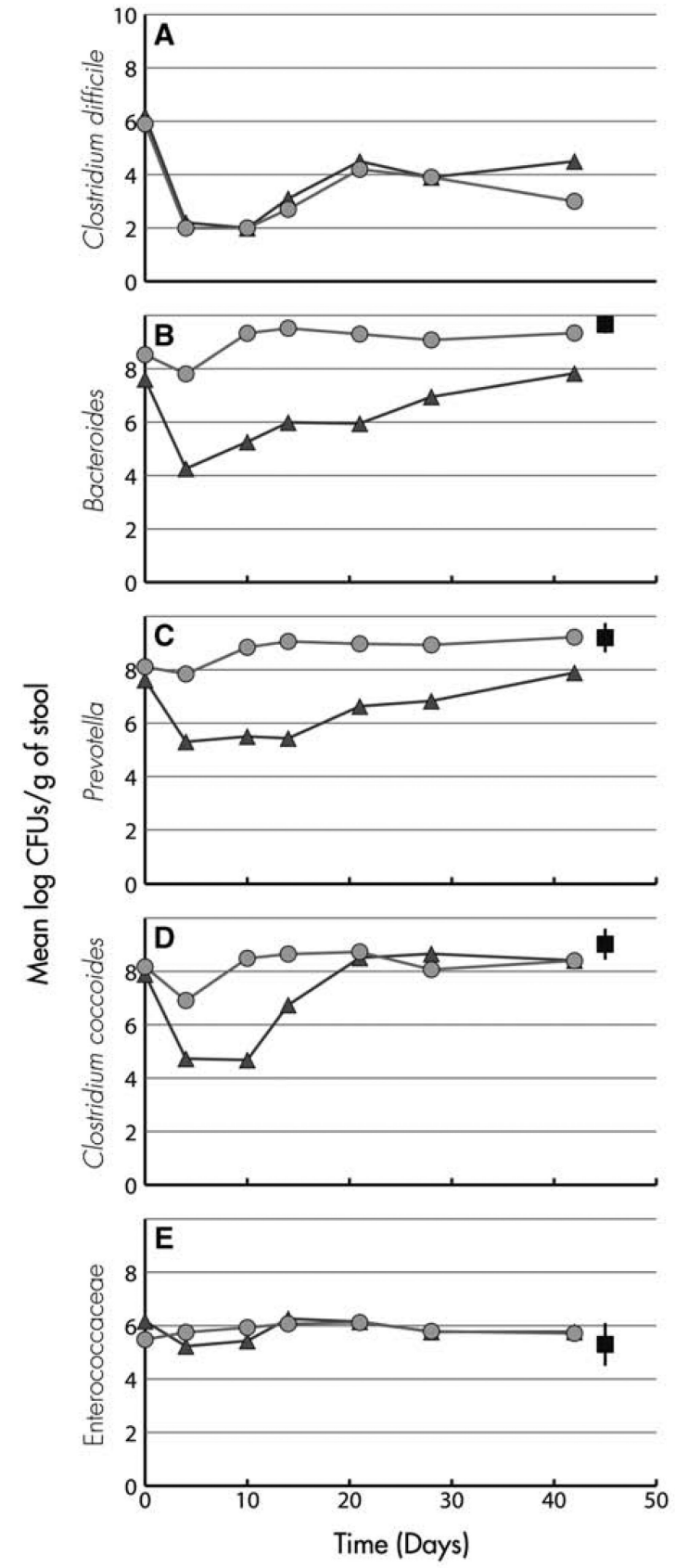

- - Fidaxomicin $\rightarrow$ Vancomycin $\rightarrow$ Healthy individuals

Figure 3.

Example graphs from student case-study sheets. Students use these graphs to interpret fluctuations in microbial populations in response to antibiotic treatment of patients with $C$. difficile infection. (Graphs recreated from published data in Louie et al., 2012.) 


\section{Table 1}

\section{How do small things make a big difference? Unit overview.}

\begin{tabular}{|l|l|l|}
\hline Lesson & Title & Description \\
\hline 1 & $\begin{array}{l}\text { How did the tree of life change through } \\
\text { history? }\end{array}$ & $\begin{array}{l}\text { Students learn about the nature of science as they examine how and why the tree-of-life } \\
\text { model has changed through history. }\end{array}$ \\
\hline 2 & $\begin{array}{l}\text { What is the current model of the tree of } \\
\text { life? }\end{array}$ & $\begin{array}{l}\text { Students focus on the current molecular three-domain tree of life as they read about Carl } \\
\text { Woese's discovery of archaea and examine simulated DNA sequences to model how } \\
\text { molecular evidence can be used to determine evolutionary relationships. }\end{array}$ \\
\hline 3 & What are microbes? & $\begin{array}{l}\text { Students define the term "microbe" and learn about the diversity of microbial shapes, } \\
\text { sizes, domains, habitats, and metabolic properties through a video and discussion, an } \\
\text { activity on microbial scale, and constructing a microbe mural. }\end{array}$ \\
\hline 4 & $\begin{array}{l}\text { What does a microbial ecosystem look } \\
\text { like? }\end{array}$ & $\begin{array}{l}\text { Students explore microbial ecosystems by developing and manipulating a model of } \\
\text { nutrient cycling in a Winogradsky column. }\end{array}$ \\
\hline 5 & $\begin{array}{l}\text { How do microbes interact with } \\
\text { humans? }\end{array}$ & $\begin{array}{l}\text { Students are introduced to the diverse microbial communities that live in and on humans } \\
\text { by reading adapted primary literature and popular science news articles and by } \\
\text { developing scientific models. }\end{array}$ \\
\hline 6 & $\begin{array}{l}\text { What can happen when my } \\
\text { microbiome is disturbed? }\end{array}$ & $\begin{array}{l}\text { Through a case study based on a published scientific paper, students analyze data to } \\
\text { investigate effects of a disturbance to the human microbial ecosystem. }\end{array}$ \\
\hline
\end{tabular}


Table 2

Connections to A Framework for K-12 Science Education for grades 9-12 (National Research Council, 2012).

\begin{tabular}{|c|c|c|}
\hline Disciplinary Core Ideas ${ }^{a}$ & Scientific Practices $b$ & Crosscutting Concepts $c$ \\
\hline $\begin{array}{l}\text { LS2.A: Interdependent relationships in } \\
\text { ecosystems } \\
\text { Ecosystems have carrying capacities resulting } \\
\text { from biotic and abiotic factors. The } \\
\text { fundamental tension between resource } \\
\text { availability and organism populations affects } \\
\text { the abundance of species in any given } \\
\text { ecosystem. } \\
\text { LS2.C: Ecosystem dynamics, functioning, } \\
\text { and resilience } \\
\text { If a biological or physical disturbance to an } \\
\text { ecosystem occurs, including one induced by } \\
\text { human activity, the ecosystem may return to its } \\
\text { more or less original state or become a very } \\
\text { different ecosystem, depending on the complex } \\
\text { set of interactions within the ecosystem. } \\
\text { LS4.D: Biodiversity and humans } \\
\text { Biodiversity is increased by formation of new } \\
\text { species and reduced by extinction. Humans } \\
\text { depend on biodiversity but also have adverse } \\
\text { impacts on it. Sustaining biodiversity is } \\
\text { essential to supporting life on Earth. } \\
\text { *Note: The lessons address aspects of these } \\
\text { DCIs in the context of microbiology and } \\
\text { human-microbe interactions. }\end{array}$ & $\begin{array}{l}\text { Developing and using models } \\
\text {-Develop, revise, and/or use a model based } \\
\text { on evidence to illustrate and/or predict the } \\
\text { relationships between systems or between } \\
\text { components of a system. } \\
\text { Analyzing and interpreting data } \\
\text {-Analyze data using tools, technologies, } \\
\text { and/or models (e.g. computational, } \\
\text { mathematical) in order to make valid and } \\
\text { reliable scientific claims or determine an } \\
\text { optimal design solution. } \\
\text { •Evaluate the impact of new data on a } \\
\text { working explanation and/or model of a } \\
\text { proposed process or system. } \\
\text { Engaging in argument from evidence } \\
\text {-Construct, use, and/or present an oral and } \\
\text { written argument or counter-arguments } \\
\text { based on data and evidence. }\end{array}$ & $\begin{array}{l}\text { Cause and effect } \\
\text { Suggest cause and effect relationships to } \\
\text { explain and predict behaviors in complex } \\
\text { natural and designed systems. Recognize } \\
\text { changes in systems may have various } \\
\text { causes that may not have equal effects. } \\
\text { Patterns } \\
\text { Observe patterns in systems at different } \\
\text { scales and cite patterns as empirical } \\
\text { evidence for causality in supporting } \\
\text { explanations of phenomena. } \\
\text { Systems and system models } \\
\text { Use models (e.g., physical, mathematical, } \\
\text { computer models) to simulate the flow of } \\
\text { energy, matter, and interactions within and } \\
\text { between systems at different scales. }\end{array}$ \\
\hline
\end{tabular}

${ }^{a}$ Taken from Next Generation Science Standards (NGSS), Appendix E: Disciplinary Core Idea Progression, pp. 5-6 (available online at http:// www.nextgenscience.org/next-generation-science-standards).

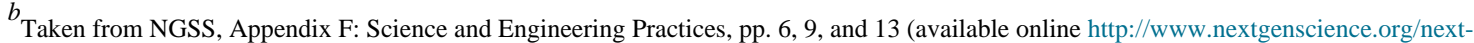
generation-science-standards)

${ }^{c}$ Taken from NGSS, Appendix G: Crosscutting Concepts, pp. 5, 6, and 8 (available online at http://www.nextgenscience.org/next-generationscience-standards). 
Table 3

Connections to Next Generation Science Standards (NGSS Lead States, 2013).

\begin{tabular}{|l|l|}
\hline Performance Expectations & $\boldsymbol{a}$ \\
\hline HS-LS2-2 & $\begin{array}{l}\text { Use mathematical representations to support and revise explanations based on evidence about factors affecting biodiversity and } \\
\text { populations in ecosystems of different scales. }\end{array}$ \\
\hline HS-LS2-6 & $\begin{array}{l}\text { Evaluate the claims, evidence, and reasoning that the complex interactions in ecosystems maintain relatively consistent numbers } \\
\text { and types of organisms in stable conditions, but changing conditions may result in a new ecosystem. }\end{array}$ \\
\hline HS-LS4-5 & $\begin{array}{l}\text { Evaluate the evidence supporting claims that changes in environmental conditions may result in (1) increases in the number of } \\
\text { individuals of some species, (2) the emergence of new species over time, and (3) the extinction of other species. }\end{array}$ \\
\hline
\end{tabular}

${ }^{a}$ Taken from NGSS (available online at http://www.nextgenscience.org/next-generation-science-standards). 
Table 4

Descriptions of student readings on human-microbe interactions.

\begin{tabular}{|l|l|}
\hline Title & Description \\
\hline $\begin{array}{l}\text { Microbes That Affect Our Body } \\
\text { Weight }\end{array}$ & $\begin{array}{l}\text { Students learn about mutualistic relationships between a human and a type of archaea and bacteria that } \\
\text { live in the gut. Graphs help illustrate how these relationships may explain the connection between body } \\
\text { weight and the gut microbiota. (References: Samuel \& Gordon, 2006; Mathur et al., 2013.) }\end{array}$ \\
\hline Our Skin Microbiome & $\begin{array}{l}\text { Students learn that there is a huge number and diversity of microbes living on human skin. Different areas } \\
\text { of the body are different types of habitats that host varying populations of microbes. Scientists cannot yet } \\
\text { explain the role of all the microbes, but many think that these native microbes form a protective shield by } \\
\text { outcompeting harmful microbes. (References: Grice et al., 2009; Grice \& Segre, 2011; Kong, 2011; } \\
\text { Figure 2) }\end{array}$ \\
\hline $\begin{array}{l}\text { Microbes Educate Immune } \\
\text { Cells }\end{array}$ & $\begin{array}{l}\text { Students analyze data from a published study that indicates a link between exposure to microbes and the } \\
\text { stimulation of T cells in response to disease. (References: Vignali et al., 2008; Atarashi et al., 2011) }\end{array}$ \\
\hline $\begin{array}{l}\text { Intestinal Microbiota } \\
\text { Development in Infants }\end{array}$ & $\begin{array}{l}\text { Students analyze data tables and graphs to learn about how differences in babies' early exposure to } \\
\text { microbes can affect the composition of their microbiome. (Reference: Palmer et al., 2007) }\end{array}$ \\
\hline $\begin{array}{l}\text { Microbes and the Blood-Brain } \\
\text { Barrier }\end{array}$ & $\begin{array}{l}\text { Students learn how microbes can be harmful if they overpopulate or enter a part of the body where they } \\
\text { do not belong. A particular example covered is how Listeria can enter the central nervous system and } \\
\text { cause meningitis. (Reference: Kim, 2008) }\end{array}$ \\
\hline $\begin{array}{l}\text { Using Microbes as Treatment of } \\
\text { Bacterial Infection }\end{array}$ & $\begin{array}{l}\text { Fecal transplants are an innovative and potentially effective new way to treat intestinal bacterial } \\
\text { infections. Students read a news article discussing the idea behind the treatment method and the results of } \\
\text { clinical trials that test it. (Reference: Rowan, 2012) }\end{array}$ \\
\hline
\end{tabular}


Table 5

An example rubric for evaluating student models.

\begin{tabular}{|l|l|l|l|}
\hline & \multicolumn{3}{|c|}{ Level } \\
\hline Criterion & $\mathbf{0}$ & $\mathbf{1}$ & $\mathbf{2}$ \\
\hline $\begin{array}{l}\text { Explanatory Power of } \\
\text { a Model }\end{array}$ & $\begin{array}{l}\text { Model does not explain the } \\
\text { scientific phenomenon being } \\
\text { investigated }\end{array}$ & $\begin{array}{l}\text { Model partially explains a scientific } \\
\text { phenomenon: model includes both } \\
\text { accurate and inaccurate descriptions of } \\
\text { the phenomenon, based on scientific } \\
\text { readings and data }\end{array}$ & $\begin{array}{l}\text { Model explains a scientific } \\
\text { phenomenon: model accurately } \\
\text { describes the phenomenon, based on } \\
\text { scientific readings and data }\end{array}$ \\
\hline $\begin{array}{l}\text { Explicit Use of Data to } \\
\text { Support Model }\end{array}$ & $\begin{array}{l}\text { Model does not use data for } \\
\text { support }\end{array}$ & $\begin{array}{l}\text { Model uses appropriate and } \\
\text { inappropriate or insufficient data for } \\
\text { support }\end{array}$ & $\begin{array}{l}\text { Model uses appropriate and } \\
\text { sufficient data for support }\end{array}$ \\
\hline Revision of a Model & $\begin{array}{l}\text { Model is not revised and does } \\
\text { not reflect new scientific } \\
\text { information }\end{array}$ & $\begin{array}{l}\text { Model is revised to reflect some new } \\
\text { scientific information }\end{array}$ & $\begin{array}{l}\text { Model is revised to reflect all the } \\
\text { new scientific information }\end{array}$ \\
\hline
\end{tabular}

